Article

\title{
Evaluating Physical and Fiscal Water Leakage in Water Distribution System
}

\author{
Suraj Kumar Bhagat ${ }^{1,2} \mathbb{D}^{-}$, Tiyasha ${ }^{1,2} \mathbb{D}^{-}$, Wakjira Welde ${ }^{2}$, Olana Tesfaye ${ }^{2}$, Tran Minh Tung ${ }^{1}$, \\ Nadhir Al-Ansari ${ }^{3} \mathbb{D}$, Sinan Q. Salih ${ }^{4}$ and Zaher Mundher Yaseen ${ }^{5, * \mathbb{D}}$ \\ 1 Faculty of Civil Engineering, Ton Duc Thang University, Ho Chi Minh City, Vietnam; \\ 186204003@student.tdtu.edu.vn (S.K.B.); 186204004@student.tdtu.edu.vn (T.); \\ tranminhtung@tdtu.edu.vn (T.M.T.) \\ 2 Department of Civil Engineering, Institute of Technology, Ambo University, Ambo, Ethiopia; \\ wakjiraceng@gmail.com (W.W.); olanatesfaye21@gmail.com (O.T.) \\ 3 Civil, Environmental and Natural Resources Engineering, Lulea University of Technology, 97187 Lulea, \\ Sweden; nadhir.alansari@ltu.se \\ 4 Institute of Research and Development, Duy Tan University, Da Nang 550000, Vietnam; \\ sinanq.salih@duytan.edu.vn \\ 5 Sustainable Developments in Civil Engineering Research Group, Faculty of Civil Engineering, \\ Ton Duc Thang University, Ho Chi Minh City, Vietnam \\ * Correspondence: yaseen@tdtu.edu.vn; Tel.: +84-033-498-7030
}

Received: 21 May 2019; Accepted: 25 September 2019; Published: 8 October 2019

\begin{abstract}
With increasing population, the need for research ideas on the field of reducing wastage of water can save a big amount of water, money, time, and energy. Water leakage (WL) is an essential problem in the field of water supply field. This research is focused on real water loss in the water distribution system located in Ethiopia. Top-down and bursts and background estimates (BABE) methodology is performed to assess the data and the calibration process of the WL variables. The top-down method assists to quantify the water loss by the record and observation throughout the distribution network. In addition, the BABE approach gives a specific water leakage and burst information. The geometrical mean method is used to forecast the population up to 2023 along with their fiscal value by the uniform tariff method. With respect to the revenue lost, $42575 \mathrm{Br}$ and 42664 Br or in $1562 \$$ and $1566 \$$ were lost in 2017 and 2018, respectively. The next five-year population was forecasted to estimate the possible amount of water to be saved, which was about $549,627 \mathrm{~m}^{3}$ and revenue $65,111 \$$ to make the system more efficient. The results suggested that the majority of losses were due to several components of the distribution system including pipe-joint failure, relatively older age pipes, poor repairing and maintenance of water taps, pipe joints and shower taps, negligence of the consumer and unreliable water supply. As per the research findings, recommendations were proposed on minimizing water leakage.
\end{abstract}

Keywords: water leakage; non-revenue water; bottom-up; top-down approach; bursts and background estimates; Ethiopia

\section{Introduction}

Water leakage is like a worm in the water distribution system where the overall system may look healthy and working efficiently yet it is slowly sucking the life out of it. Water Loss Assessment (WLA) investigations have been done by many studies. It encompasses the estimation of the amount of WL of a specific site regardless of addressing the leaky location. At the beginning of the nineteenth century, WLA was based on "guess estimation" method than a precise tool [1]. Recently, WLA and Water Loss Management (WLM) studies have been increased significantly. International Water Association 
(IWA) and the American Water Works Association (AWWA) introduced a new set of concepts and methodologies to improve WLA and WLM [1,2].

Researchers and engineers have realized that $\mathrm{WL}$ is not about losing money but also water resources lost, which took time, money, and effort from the water network system and then distribution system [3,4]. This is the initial loss of good quality water. Leaked water returns with contamination through the leakage point, which may itself raise a completely new issue [5]. Safe distribution of water is the main motto of the water authorities. Leakage also raises questions on loyalty and reliability of the water supply system and their operationally and serviceability [6]. WL is also about restrictive energy, clean water, supplying more water, and limiting carbon footprints going to the global population $[7,8]$. Water loss is sought off as a common problem for the water utility system and a nuisance to the management [9].

The most affected countries by water loss are low-income countries who cannot afford to lose any more precious water. In developing countries, the annual volume of non-revenue water (NRW) was estimated at about 45 million cubic meters in the distribution networks [10]. The total cost was estimated at nearly 3 billion dollars per year due to WL. About 90 million people would be possible to serve by saving half of those losses [11]. Nearly, 30 million cubic meters of water is delivered every day to customers, but are not invoiced because of pilferage, employee's corruption, and poor metering [12]. In low and middle-income countries, 60 million cubic meters of water was found to be lost daily through leaky pipes [10]. In sub-Saharan Africa (which includes 46 countries including Ethiopia), NRW was estimated at around $600 \$$ million per year from the distribution utilities. This significant portion of finding can help to estimate and accomplish the Millennium Development Goals in better-quality access to water and sanitation by the United Nations [13].

Water loss in the distribution system has been reported, globally. WL of NRW is hard to estimate due to its incomprehensibility and faintness [14]. The IWA task force and AWWA task force produced guidance and best management practice (BMP) strategies, respectively to ease the quantifying water losses and compare the effectiveness of their management policies [2,15]. Leaky distribution systems increase the cost of water loss and affect adversely on water quality as well [16]. There are many tools which came to existence to understand the water loss in the distribution system and to mitigate this confusing problem. A bottom-up approach, minimum night flow (MNF), and bursts and background estimates (BABE) analysis have been reported effectively to assess the water losses with excessive assumptions, accurate pressure measurement, and hydraulic model calibration, respectively [17-20]. Therefore, these models are feasible for low-income countries like Ethiopia. Top-down is neither a pressure-dependent nor a total fieldwork-based method. The top-down approach requires data such as water balance and basic system data (water volumes, heads, and energy bills) to assess the percentage of water losses $[19,20]$. The burst and background estimate (BABE) was accepted worldwide as it is a very easy and pragmatic approach to the complex and confusing problem of leakage in the distribution system [21,22]. Reduced network models (RNM) was able to isolate leakage in the water supply networks, effectively. Comparison between the expected behaviour and actual measurement can be done to isolate the leakage [23]. The first time in 2000, parallel computing recognized pressure reducing valves to adequately locate, to minimize the leakage problem in water network [24,25].

WL consists of real losses and apparent losses [10]. Real loss is also named as physical losses, which means it leaks out of the pipe by bursts and leakages. The apparent loss is also called commercial losses. Apparent water loss means consumer used the water without paying due to the meter being under review or registration, meter error, billing error, and data miss-handling. The amount of unauthorized consumption 'Water used without bill' is the main difference between NRW and WL [15].

The water supply service in Kisumu (Kenya) and the national water company of Ghana lost half of its water supply due to WL. The state water board of Bache (Nigeria) estimated its loss may reach up to $75 \%$ in coming years, moreover this system was unable to calculate its total water supply due to the traditionally implemented system $[1,26,27]$. Based on the study, results indicated that the total loss 
of water of Addis Ababa city was $54,094,795 \mathrm{~m}^{3}$, out of $120,088,391 \mathrm{~m}^{3}$ supplied by the system and the loss was estimated to be $45 \%$ of the total supplied to the distribution system [28].

As per the millennium, a development goal was targeted by the UN to achieve better practices in African cities in which Addis Ababa is one of them. Ethiopia being the second-most populous country of Africa and Addis Ababa being the capital, which is the fasting growing urban habitat. The problem was realized long before the urban water crisis and threatened water resources. During the initial study 40 percent of water was found uncounted [29]. Ethiopia has progressed in the field of higher education, it had 33 public universities and 61 private institutes with overall 757,000 students by 2014 as per UNESCO Institute for statistic [30]. To accommodate the huge population, there was a need for the large water supply and distribution system. When there is such a water supply system, there will be WL. More study is required in the case of real losses to figure out the reason of the loss and how it can be overcome and minimized, in context to developing and low-income countries where there is need of a low-cost solution and less expensive distribution system. In Ethiopia, water loss in higher educational institutions is a serious problem. However, adequate research has missed this issue so far. The estimation of the water loss is itself a challenge and it may arise in the case of improper water billed to the institute and water consumed within it.

This paper focuses on the calibration of different variables of water leakage of an educational institute (Ambo University, Ethiopia) such as quantification, addressing the components of WL, and fiscal loss in the location with predictive possibilities of water loss and revenue loss in the next four years in the study area. In addition, with some recommendations, that would assist to minimize the water leakage to save the natural resources along with energy conservation, which will help the government, organization, and the ecosystem. This study also opens another research objective with different variables for a different kind of institute or organization of the developing countries with a similar situation.

The next session describes briefly the study area and the subdivision of the blocks where the assessment has been done. The third section deals with methods to evaluate the quantity of leaky water, localized loss comparison, cause of water loss, revenue loss, and future prediction (up to 2023) of water loss and economic loss. The fourth section discusses and analyses the resulting outcome of the finding using the methods described earlier. The last part is the recommendations which deal with, how to lessen the water loss with different contemporary techniques such as awareness among consumers, localized physical measurement, and use of AI models.

\section{Methodology}

\subsection{Case Study Description}

The study area is at the Institute of Technology (IoT) campus, Ambo University (AU), Ethiopia which is located in Ambo City, Kebele- 02 at $3 \mathrm{~km}$ from the center of Ambo city (bus station). Ambo city is located in the Oromia regional state, West Shoa zone and 125 kilometres west of Addis Ababa (the capital city of Ethiopia) and illustrated in Figure 1. Institute of Technology (IoT), which is one of the campuses of the Ambo University, is dedicated to 13 engineering departments and house to 6186 students in 2018. The total study area covered about $1.444 \mathrm{~km}^{2}$.

Currently, the Ambo Urban Water Supply and Sewerage Service Enterprise (AUWSSE) office is distributing around 220,000 $\mathrm{m}^{3}$ /day of water to the whole Ambo town, which is fetched from Huluka River, Ambo. Institute of Technology (IoT) campus has been getting water supply from AUWSSE as well. AUWSSE installed the gravitational distribution system due to its slant geographical condition; this study also reveals that the slope pattern of Ambo and the campus area itself consists of $10 \%-15 \%$ of slope [31]. 


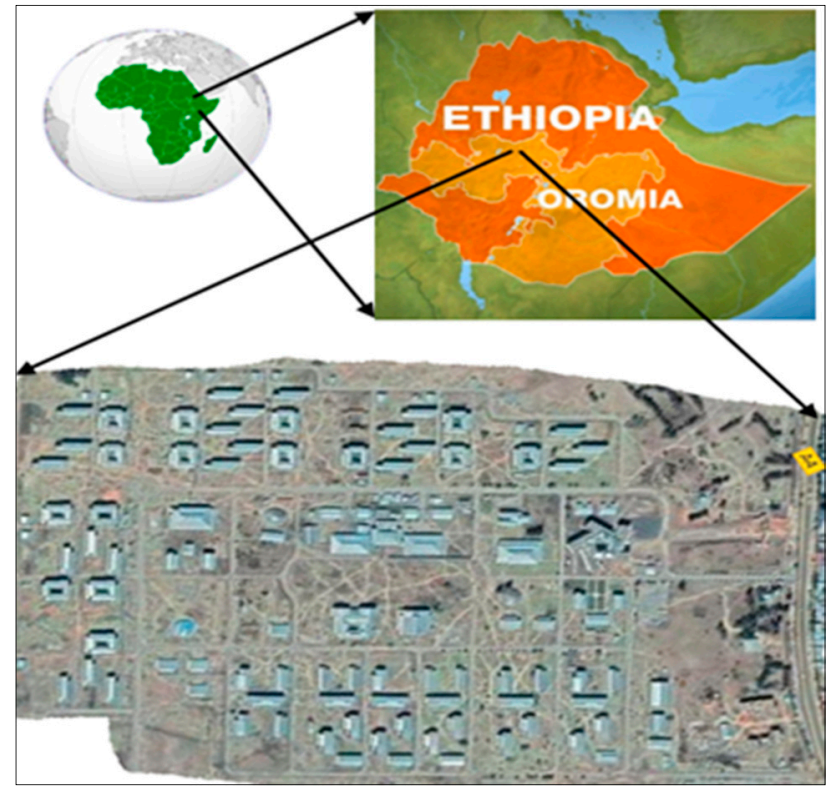

Figure 1. Location of study site Ambo City (Oromia regional state, West Shoa zone, Ethiopia, East Africa).

\subsection{Methods to Assess the Data by Top-Down Approach}

The top-down approach was used in this study because of lack of advance measuring instrument, as well as lack of funds for installing sensors which can detect and estimate the water loss at a specific area. Top-down approach allowed researchers to evaluate an individual component of the system, i.e., the whole campus distribution network as a system and individual blocks as a component. Then, the individual components water balance, water consumption, number of consumer and possible detection of leakage points and origin of the loss at the point was estimated [22].

For water balancing, IWA standards were taken which included total water intake, water loss, billing information, revenue water, non-revenue water, as well as an apparent and real loss. The apparent loss was taken as nil since there was no considered consumer or metering inaccuracy whereas real losses were taken in account as leakages due to transmission, overflow, connection fault, etc. [32,33].

Based on the information gathered from onsite data collection, various calculation and assessment of water relation and its correlation to the wastage of the revenue have been divided into the following calculations $[19,20,34]$ :

Visual water loss detection, reason, and quantification of the loss water were studied for 15 blocks. Water loss ( $\mathrm{WL}_{\mathrm{p}}$, in liter/day) at each point was calculated using Equation (1) by converting from L/sec.

ii Liter per capita consumption, water consumption per month, and total water loss in the study area per month from Equations (2)-(4).

iii Amount of water consumed within the campus and amount spent on water bill per month in the dollar (January 2017 to June 2018).

\subsection{Water Loss Analysis by BABE Methods}

The information about the amount of water entering the campus each month with their corresponding amount paid in Ethiopian Birr (Br) has been collected from the AUWSSE office, which was used in the determination of water loss from the supplied water and economical effect of water loss. The campus was divided into blocks and intensive observation of visual leakage was noted down. The BABE approach is not a holistic approach but more on the point source thus more 
appropriate in this case where individual block as well as number of leakage point in each block was calculated as $V_{p}$ (Volume of leakage at a point) given by equation (1) and then all of them were summed to get the system water loss value as $W L_{t}$ (Total water loss for the study area) given by equation (2). In the BABE approach theory, quantification of particular leak or burst is done by using the average flow rate (by taking manual concord value reading for leakage at each point calculating the amount of water loss by measuring flask and the leak duration by stopwatch) and duration of specific leakage, as noted below $[15,19,20,22]$.

$$
V_{p}=Q \times T
$$

where, $V_{p}=$ Volume of leakage at a point $(L), Q=$ Leak flow rate (L/sec) and $T=$ Leak duration (Sec).

Water loss $\left(W L_{b}\right)$ at one block was estimated by summing up all the identified leakage points of the block.

$$
\frac{W L_{t}}{\text { month }}=\frac{W L_{b 1}+W L_{b 2}+\cdots+W L_{b n}}{\text { month }}
$$

where, $W L_{t}=$ Total water loss for the study area, $W L_{b 1}=$ Water loss at one block in liter.

\subsection{Water Consumption in the IoT, Campus}

The campus also houses residents thus the population in the campus was found to be 6810 in 2017 and 7023 till June 2018. The average daily consumption was derived by using annual consumption data, number of population, and total water consumption over the year. The average daily per capita consumption of IoT, Ambo University was derived using the following jargons [34,35]:

$$
C C=\frac{A C \times 1000}{P N \times 365}
$$

where: $C C$ is capital consumption in 1/person/day, $A C$ is annual consumption in $\mathrm{m}^{3}, P N$ is population of IoT.

Then, water consumption was calculated using the following equation where water intake was collected from AUWSSE and monthly water loss was equated from Equation (2)

$$
\frac{\text { Water consumption }}{\text { month }}=\frac{\text { Water intake }}{\text { month }}-\frac{\text { Gross water loss }}{\text { month }}
$$

Measurement of water loss was conducted at different places of the distribution system. At the location where water loss was detected, the volume of water was measured using a function of the average runtimes and average flow rates for different types of leakage [36]. The data has been collected from the concern authority with different time of sampling. To estimate the per capita demand, the total demand for water supply was obtained from the AUWSSE office.

\subsection{Water Tariffs Schemes}

As per the AUWSSE office, Uniform Tariff scheme is applicable for governmental building such as IoT, AU. This tariff ensures social equity. Uniform tariff scheme is the fixed price regardless of the quantity of water used by the consumer. Process of tariff revision is simple, easy to understand for consumers, and organizations pay according to the amount of water they actually use $[37,38]$. Due to lack of periodical proper monitoring, this also fails to control accurately and genuinely, especially in-line to leakage [39]. The different data analyzed to evaluate the total NRW of IoT, and their cost in USD.

\subsection{Population Forecasting}

In this study, the geometrical increase method is used to forecast the population. Preference of the method for a particular university is needed to consider based on, overall current situations and since it is a new campus; thus, there is not much data from the past years. For the fast-growing university, 
where relatively high economic activity observed and at the same time, continuous expansion of the university due to various reasons, the geometrical increase method is more preferred for the same kind of project area as mentioned by [40]. The population starting from 2014-2018 has been collected from IoT, Ambo University registrar office, and human resource office. Then, after population and NRW up to three decades have been calculated in $\mathrm{m}^{3} /$ year and USD/year, respectively.

$$
P_{n}=P\left(\frac{1+I_{G}}{100}\right) n
$$

where; $P_{n}$ is population in n-number of year, $P$ is present population, $I_{G}$ is geometric mean in percent $(\%)$, and $n$ is number of year.

\section{Result and Discussion}

\subsection{Analysis of Water Distribution System of the Campus}

The water network map of the entire campus was collected from the "TNT construction \& Trade Ethiopia" company to follow it during the data collection. The campus does not have a proper distribution station and gate valve points, which made controlling of the system complicated. This also created a barrier for the appropriate working of the water distribution, which was also contributed by the lack of properly defined supply pipe network mainly comprised of main pipes, sub-main pipe, distribution pipe, and plumbing pipes that cover the major part of the campus. The network was not divided as per the valves and no material specification.

The water distribution line in the study area consisted of different diameters such as mainline with a diameter of $200 \mathrm{~mm}$ and sub mainline and with a diameter of $150 \mathrm{~mm}$. Distribution line with a diameter of $80 \mathrm{~mm}$ and $65 \mathrm{~mm}$ and connection line with a diameter of $50 \mathrm{~mm}$ and $40 \mathrm{~mm}$ (b). The plumbing inside the building with a diameter of $32 \mathrm{~mm}$ and $20 \mathrm{~mm}$ was installed. The conventional approach of distributing the water throughout the campus was used which did not follow the proper detailed plumbing details. This traditional approach leads to complications in the water management system in-line to the water supply, water storage, water leakage, and water monitoring. The complications were raised due to the less flexible, non-responsive, and decentralized working system, which were interconnected without a proper arrangement of each element of the distribution system.

\subsection{Water Consumption, Water Loss and Water Bill}

The study of the IoT campus is a real-life study of the distribution system with one source of water intake, i.e., from AUWSSE and which is distributed to 7023 consumers as per the human resource department of IoT. Using the complete water supply coverage of the town may not be precise enough to the realize the volume of consumption per capita of the IoT, AU campus. For this reason, average daily demand per capita is calculated by using monthly consumption data and the number of population of IoT as it has been studied [41]. The total amount of water that enters the IoT, AU campus for each month of 2017 and 2018 (up to June) were collected from the AUWSSE office. Table 1 illustrates that the total amount of water entered in the campus in 2017 and 2018 was $311,327 \mathrm{~m}^{3} /$ year and $188,925 \mathrm{~m}^{3} /$ year, respectively. Then, further average water consumption per year has been calculated as $21,213 \mathrm{~m}^{3} /$ year and 26,757 m³ /year approximately for 2017 and 2018 as listed in Table 1 using equation (4). For both 2017 and 2018, the average amount of water consumed as liter per person per day (LPCD) was estimated as 125.2 LPCD and 177.4 LPCD, respectively using equation (3). Total average monthly water loss was taken at about $4730 \mathrm{~m}^{3}$ for both of the years as consecutive using equation (2). For the sake of calculation, the water loss has been assumed the same for all the months because of lack of data and lack of human resources. Thus, unaccounted for water was (UFW) already on the higher side as compared to the size of the institute. 
Table 1. Details of water intake, water consumption (WC), water leakage (WL), fiscal loss in Br and use monthly-wise.

\begin{tabular}{|c|c|c|c|c|c|c|}
\hline Year & Month & $\begin{array}{l}\text { Water Intake } \\
\text { per Month in } \\
\mathrm{m}^{3}\end{array}$ & $\begin{array}{c}\text { WC per } \\
\text { Month in } \\
\mathrm{m}^{3}\end{array}$ & $\begin{array}{c}\text { WL per } \\
\text { Month in } \\
\mathrm{m}^{3}\end{array}$ & $\begin{array}{l}\text { Fiscal Loss } \\
\text { (Br) }\end{array}$ & $\begin{array}{c}\text { Fiscal Loss } \\
\text { (\$) }\end{array}$ \\
\hline \multirow{12}{*}{2017} & January & 32,201 & 27,471 & 4730 & 42,573 & 1562 \\
\hline & February & 25,641 & 20,911 & 4730 & 42,577 & 1562 \\
\hline & March & 25,849 & 21,119 & 4730 & 42,573 & 1562 \\
\hline & April & 25,849 & 21,119 & 4730 & 42,573 & 1562 \\
\hline & May & 23,541 & 18,811 & 4730 & 42,564 & 1562 \\
\hline & June & 24,497 & 19,767 & 4730 & 42,573 & 1562 \\
\hline & July & 35,200 & 30,470 & 4730 & 42,578 & 1562 \\
\hline & August & 26,763 & 22,033 & 4730 & 42,561 & 1562 \\
\hline & September & 23,942 & 19,212 & 4730 & 42,578 & 1562 \\
\hline & October & 24,153 & 19,423 & 4730 & 42,606 & 1563 \\
\hline & November & 23,541 & 18,811 & 4730 & 42,586 & 1563 \\
\hline & December & 20,150 & 15,421 & 4729 & 42,563 & 1562 \\
\hline \multirow{2}{*}{\multicolumn{2}{|c|}{$\begin{array}{c}\text { Total } \\
\text { Average }\end{array}$}} & 311,327 & 254,567 & 56,759 & 510,906 & 18,749 \\
\hline & & 25,944 & 21,214 & 4730 & 42,575 & 1562 \\
\hline \multirow{6}{*}{2018} & January & 21,980 & 17,250 & 4730 & 42,571 & 1562 \\
\hline & February & 25,200 & 20,470 & 4730 & 42,570 & 1562 \\
\hline & March & 27,807 & 23,077 & 4730 & 42,570 & 1562 \\
\hline & April & 37,626 & 32,896 & 4730 & 42,566 & 1562 \\
\hline & May & 43,744 & 39,014 & 4730 & 42,570 & 1583 \\
\hline & June & 32,568 & 27,838 & 4730 & 42,560 & 1562 \\
\hline \multirow{2}{*}{\multicolumn{2}{|c|}{$\begin{array}{c}\text { Total } \\
\text { Average }\end{array}$}} & 188,925 & 160,545 & 28,380 & 255,986 & 9394 \\
\hline & & $31,487.5$ & 26,757 & 4730 & 42,664 & 1566 \\
\hline
\end{tabular}

Average fiscal water loss was calculated by using the uniform tariff of water in the Ambo town at $9 \mathrm{Br} / \mathrm{m}^{3}$. The average cost of water loss was estimated at about $42,575 \mathrm{Br} / \mathrm{month}$ or $1562 \mathrm{USD} / \mathrm{month}$ in 2017 and 2018 also presented in Table 1. (Conversion factor used as 1 USD $=27.25 \mathrm{Br}$ as per the current date). Figure 2 clearly illustrates the variation of water intake, water consumption, and water loss along with their fiscal loss in 2017 and 2018, respectively. Figure 2 gives the idea of higher intake and consumption for May 2018, but the water loss remains the same, it shows the billing error due to the human error or meter error. Table 1 illustrated each month of water loss in $\mathrm{m}^{3}$ and their value in $\mathrm{Br}$ and $\$$. The rainy season, which comes in December would have the least value of consumption due to often water supply interruption, whereas, the summer season peak in July would bring a high amount of WL due to high pressure and uninterrupted water supply since Ethiopia only suffers from water stress, not scarcity. 


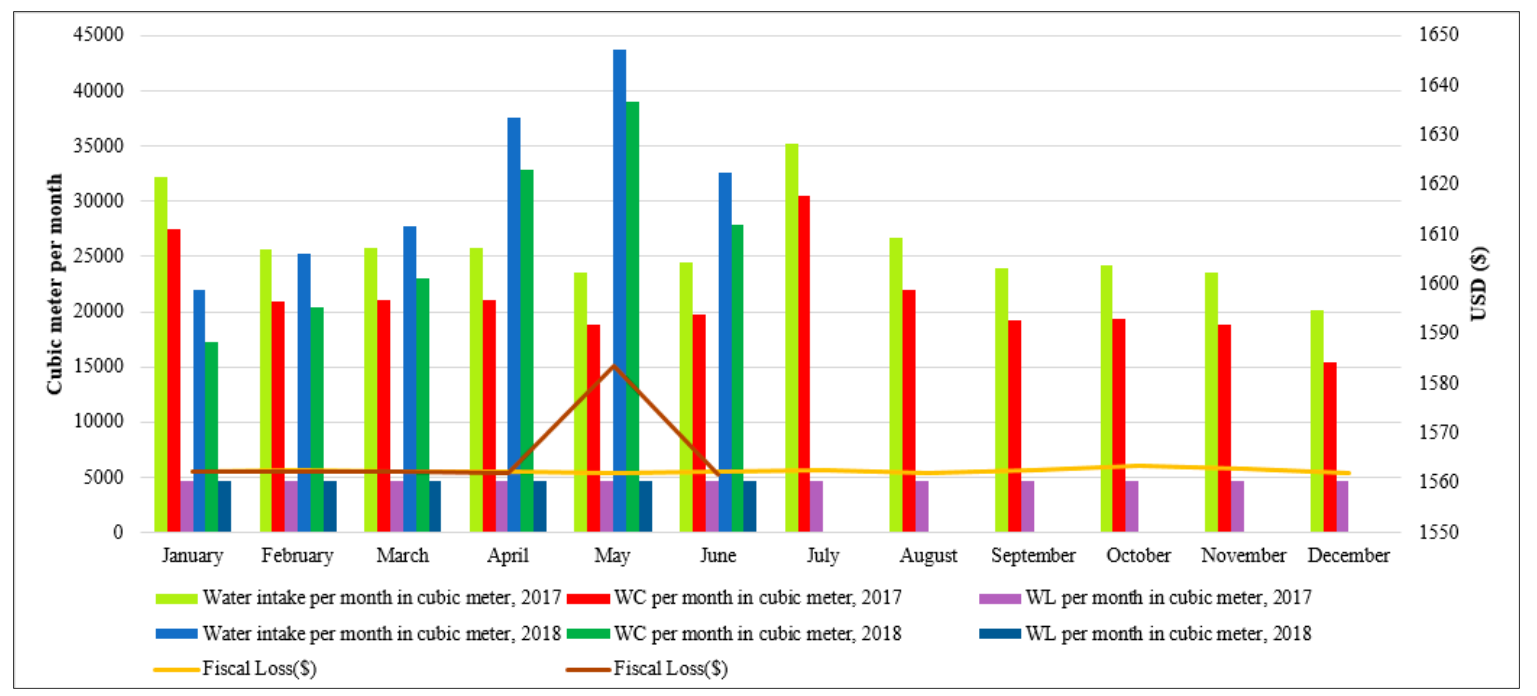

Figure 2. Details of water intake, water consumption, water loss (per month in $\mathrm{m}^{3}$ of 2017 and 2018, respectively), and their fiscal loss in $\$$.

\subsection{Water Loss per Block, Localization and Major reason for the Leakage Source}

As IoT water network systems were inter-connected to each other without separating the system with a proper joint outline, type of materials, the diameter of pipes, and distribution system details. This made it difficult for identification and calculation of the distribution of the water loss at a different spatial location. The management of IoT, Ambo University is facing the problem of water loss which is caused due to poor inspection, less or careless repair of water supply facility, improper use of water and lack of awareness. Water loss has been calculated using the BABE method for each block of the study area as per equation (1) and shown in Table 2. The table also illustrates the number of users, major visually observed reasons for water lost in each designated block, as well as the possible amount of water loss, was also depicted which was obtained by the top-down approach.

Figure 3 gives water loss in $\mathrm{m}^{3}$ /day per block (block A, B, F, H, I, J, K, L, M, N, P, V, W, X, and 110) along with its number of water users; in addition to it, Figure 3 presents the maximum (i.e., $\mathrm{B}$ block) and minimum (i.e., L block) leakage value per block.

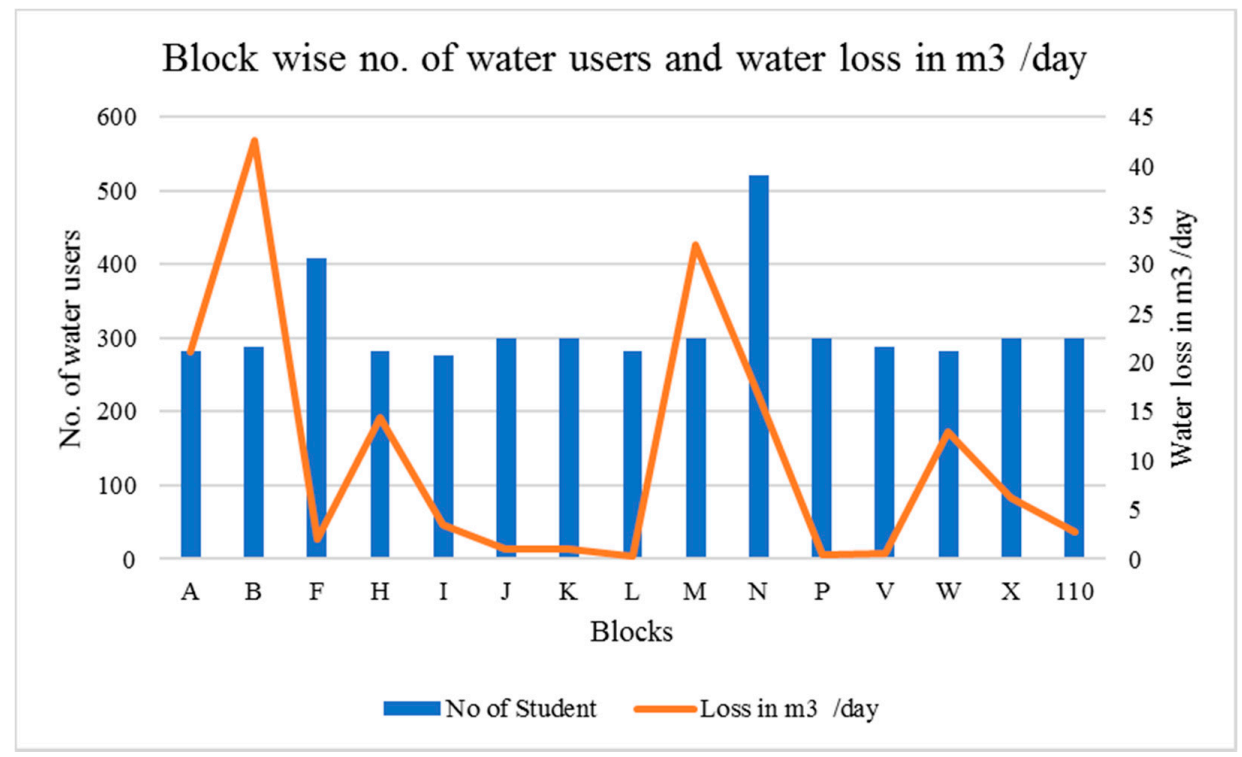

Figure 3. Water losses in $\mathrm{m}^{3}$ per block. 
Table 2. Block-wise water loss and their major reasons.

\begin{tabular}{cccc}
\hline Block & No. of Student & Loss in $\mathbf{~}^{\mathbf{3}}$ /day & Major Reasons \\
\hline A & 282 & 21.12 & Busted Pipe and Joints (BPJ) due to unreliable pressure \\
fluctuation (UPF) \\
B & 288 & 42.58 & BPJ due to due to UPF and aged materials (AM) \\
F & 408 & 1.98 & Corrosion and poor maintenance (PM) \\
H & 282 & 14.38 & Broken gate valve (BGV), Broken Tap (BT) due to AM \\
I & 276 & 3.49 & Broken cap of pipe due to PM \\
J & 300 & 1.01 & Broken valve (BV) of tap \\
K & 300 & 1.00 & Crack in pipe due to UPF and No shower fixture \\
L & 282 & 0.22 & BV of tap \\
M & 300 & 31.99 & UPF damaged valve of tap \\
N & 520 & 16.74 & BV of tap \\
P & 300 & 0.45 & Damaged shower fixture due to AM \\
V & 288 & 0.62 & BV of tap \\
W & 282 & 12.96 & BGV due to UPF \\
X & 300 & 6.27 & BGV due to PM \\
110 & 300 & 2.81 & Damaged shower fixture due to AM \\
\hline
\end{tabular}

Table 2 represents that six major reasons for water leakage have been observed by researchers such as broken gate valve (BGV), unreliable pressure fluctuation (UPF), aged material (AM), poor maintenance (PM), busted pipe and joints (BPJ), and broken tap (BT). UPF was observable more than others whereas BT were found to be least and others were averagely responsible for WL. BPJ at different places were observed in the water distribution system. Either BGV or PM of gate valve was observed throughout the water distribution system and consequently, water leakage was occurring. Some of the water outlets didnot have water taps or proper working taps. Water was wasting, continuously due to the nonstop flow due to fixtures damage (water shower outlet).

\subsection{Population Forecasting along with Financial Loss}

The population $(\mathrm{P})$ data of IoT, $\mathrm{AU}$ which used to convert annual water consumption to average daily per capita consumption is given in Table 3. Population data of 2014-2018 was collected from the registrar and human resource office of the campus with their classification and were listed in Table 4 . This classification helped to evaluate the LPCD precisely. Population forecasting has been estimated by using the geometrical increase rate method up to 2023 using equation (5). Further, the amount of water loss in meter cube per year and their values in $\mathrm{Br}$ and \$ was estimated and listed in Table 5. Table 5 displays water loss during 2019-2023, which significantly goes higher per year and their value in $\mathrm{Br}$ and $\$$ as well went up simultaneously. This water loss finding has the potential to attract the authority to rectify this problem as soon as possible. By rectifying the water loss, and thus, water and energy can be saved dramatically and approached towards the water sustainable management system.

Table 3. Water consumption (WC) in liter per person per day (LPCD) of 2017 and 2018.

\begin{tabular}{ccccc}
\hline Year & Total Population & Average WC $\left(\mathbf{m}^{3} /\right.$ year) & Average WC $\left(\mathbf{m}^{\mathbf{3}} / \mathbf{d a y}\right)$ & WC (LPCD) \\
\hline 2017 & 6810 & 311327 & 853 & 125 \\
2018 (up to June) & 7023 & 224370 & 1496 & 177 \\
\hline
\end{tabular}


Table 4. Classification of population data (source: Registrar and human resource office of Institute of Technology (IoT), Ambo University (AU)).

\begin{tabular}{cccccc}
\hline \multirow{2}{*}{ Year } & \multicolumn{3}{c}{ Population } & \multirow{2}{*}{ Total } \\
\cline { 2 - 5 } & Non-teaching Staff workers & Students & Teachers & Other workers & \\
\hline 2014 & 70 & 4022 & 221 & 229 & 4524 \\
2015 & 72 & 5448 & 244 & 240 & 6004 \\
2016 & 75 & 5864 & 276 & 258 & 6473 \\
2017 & 77 & 6120 & 329 & 284 & 6810 \\
2018 & 77 & 6186 & 382 & 378 & 7023 \\
\hline
\end{tabular}

Table 5. Population forecasted using geometrical increase rate of growth, fiscal loss forecasting, correspondingly.

\begin{tabular}{|c|c|c|c|c|c|}
\hline Year & Population & \multicolumn{2}{|c|}{ Predicted Water loss in $\mathrm{m}^{3}$ (Min Loss - Max Loss) } & Fiscal Loss (Br) & Fiscal Loss (\$) \\
\hline 2014 & 4524 & \multirow{3}{*}{\multicolumn{2}{|c|}{ Data used for only population forecasting }} & \multirow{2}{*}{\multicolumn{2}{|c|}{ NA }} \\
\hline 2015 & 6004 & & & & \\
\hline 2016 & 6473 & & & & \\
\hline 2017 & 6810 & 8512 & 199,788 & 337,447 & 12,338 \\
\hline 2018 & 7023 & 8779 & 206,037 & 348,002 & 12,724 \\
\hline 2019 & 7077 & 8846 & 207,621 & 350,678 & 12,822 \\
\hline 2020 & 7132 & 8915 & 209,235 & 353,403 & 12,921 \\
\hline 2021 & 7187 & 8984 & 210,849 & 356,128 & 13,021 \\
\hline 2022 & 7243 & 9054 & 212,491 & 358,903 & 13,122 \\
\hline 2023 & 7299 & 9124 & 214,134 & 361,678 & 13,224 \\
\hline
\end{tabular}

As indicated in Table 5, the average daily per capita water consumption of the IOT, AU has increased from the year 2017 to 2018. This shows that due to the cause of water loss, the entire campus water demand went up along with the rising population. This average per capita consumption was found to be very high while compared with the country standard used for design purpose (30 to 60 L/capita/day) as per Ethiopian Building Code Standard 9 (EBCS 9) and this difference may be the WL. Though, sustainable development goals (SDG) approach are trying to reach the standard in coming future $[8,42]$.

\section{Recommendations}

After the subterranean study, researchers produced the following recommendations to the management, to lessen the water leakage problem and stop such a huge financial loss every month:

Awareness methods can bring remarkable changes to mitigate the WL problem to the project area without any physical measurement and much more involvement of skilled people are required [43]. The study area for the initial project work can be educational institutes since students and teachers will be more receptive to the need for water-saving ideology. From such kind of organization, awareness campaign can more effectively spread throughout the region, especially for developing country where there can be less funding and personals for campaigns. A case study of Hanoi showed a potential output via state estimation and awareness using systematically assessed minimum leak in the water distribution system [44]. Such measures can substantially reduce leakages by reducing careless and negligent mistakes.

ii Leakage detection methods are concerned with its detection of frontline water leakage site [22]. Automated detection of pipe bursts approach came to the limelight, using different Artificial Intelligence (AI) tools to predict the leakage prior to its taking place with some variables like pressure and flow signal value [45]. AI has shown significance capability to deal with missing data, decreases the cost of testing [46-48], can easily classify the point source of the leakage [49], and predict the life of the distribution system components [50]. These advantages make the potential of AI models useful in developing countries where there are lacks of uniform and regular 
data, funding for data collection and testing, advanced sensors to pinpoint the leakage sources, and lack of regular maintenance system.

iii Optimal pump schedule approved methods is to meet water demand and reliable water pressure along with minimization of the leaky system and power consumption as well as an economic benefit [51]. The physical measurement method such as pressure-dependent leak detection model, which is quite impressive to minimize the leakage as early as possible and save the revenue [52]. Several small changes can make a significant sense to minimize water leakage. Longitudinal analysis qualifies changes in periodical report disclosures via description and visual to company performance and leads to prospective saving in line to water and energy [53]. Since water is a revenue using low-cost analysis can save lots of water and money. These techniques are easy to apply and learn, so people with a basic education can help in the data collection and analysis.

The above-mentioned recommendations can create great changes in the developing communities towards mitigation of WL by utilizing any of these techniques as per the scenario of the project area. All these recommendations were given keeping in mind the growing countries as they are economical, can be easily implemented and effective in water loss prevention. This is also the need of the hour for the new researchers to understand the crisis in hand and apply possible techniques to remedy it. These tools will help in managing, monitoring, and creating better economic projects, which will save water and increase the life of the distribution system.

\section{Conclusions}

This work would help to reduce the problems of water leakage and to understand the reasons of it explicitly why, how, and where water leakage is taking place commonly in the system. The average water demand was evaluated as 125.2 LPCD (liter/capita/day) and 177.4 LPCD in 2017 and 2018, respectively. This average per capita consumption was more than the country standard, used for design purpose and that is 30 to $60 \mathrm{LPCD}$ as per Ethiopian Building Code Standard (EBCS) 9 in respect to the revenue lost $42,575 \mathrm{Br}$ and $42,664 \mathrm{Br}$ or in $1562 \$$ and $1566 \$$ in 2017 and 2018, respectively. This study is the alarm for the managing authorities that it is time to understand that water is more valuable than time and money in the present crisis. In many illustrations, the problem of water loss is caused by poor operational practices, poor infrastructure, network characteristics, and bad management practice. In addition to the lack of different time scale data, periodical maintenance, and lack of motivation at the management level. Thus, the IoT, Ambo University water authority has great difficulty to locate the WL and quantifying it precisely. Thus, it is suggested that the well plan periodic management can overcome most of the issues as recommended in the previous section. Ethiopia is considered as a water-stressed area since water is there but not fit for drinking because of this, health issues are also increasing day by day. The study aims to increase awareness among the authorities of the area as well as similar areas where a large amount of water is wasted because of human ignorance and lack of awareness.

UN project is very much active in these areas and therefore, sustainable development goals approach needs more effort to reach and water leakage mitigation may help to achieve it. Uniform price policy does not bring social justice among different kinds of consumers as well as nothing that benefits the operator [54]. This study has used the top-down approach because of its simplicity in leakage assessment for such areas where there is lack of available and continuous data, obliviousness in preservation and management, which lead to lack of information in a specific occasion. However, this was the first step for the leakage study and more research has to be done considering the issues and problems in a developing country. Similarly, BABE was used because it does not use the holistic approach rather it uses the individual point source data collection system, which was more suitable in the case of this study because of lack of differentiated distribution system and lack of data. This paper's target area was to study the environment and take simple measures which can save lots of potential water and could be implemented commonly for developing areas similar to such. The initial target 
was taken as an institution because they have habitat of a large population, mostly funded by the government, and managed by common authorities.

Author Contributions: Conceptualization, S.K.B.; Data curation, W.W. and O.T.; Formal analysis, S.K.B.; Investigation, Tiyasha; Methodology, Tiyasha; Resources, S.Q.S.; Supervision, T.M.T. and N.A.-A.; Visualization, S.Q.S.; Writing—original draft, S.B. and W.W.; Writing—review and editing, Z.M.Y.

Funding: This research received no external funding.

Acknowledgments: Authors acknowledge the necessary platform and tools for successful completion of the research provided by Ambo University. Authors also would like to thanks to Ambo Urban Water Supply and Sewerage Service Enterprise (AUWSSE) office for providing the significant data for the research.

Conflicts of Interest: The authors declare no conflict of interest.

\section{References}

1. Lambert, A. Assessing Non-Revenue Water and its Components: A Practical Approach; IWA Publishing: London, UK, 2003.

2. Committee, A.W.L.C. Committee Report: Applying worldwide BMPs in water loss control. J.-Am. Water Work Assoc. 2003, 95, 65-79. [CrossRef]

3. Spulber, N.; Sabbaghi, A. Economics of Water Resources: From Regulation to Privatization; Springer Science \& Business Media: Dordrecht, The Nertherlands, 2012; Volume 13, ISBN 940114866X.

4. Loucks, D.P.; Van Beek, E. Water Resource Systems Planning and Management: An Introduction to Methods, Models, and Applications; Springer: Cham, Switzerland, 2017; ISBN 3319442341.

5. Hunaidi, O.; Chu, W.; Wang, A.; Guan, W. Detecting leaks in plastic pipes. J.-Am. Water Work Assoc. 2000, 92, 82-94. [CrossRef]

6. Venkatesh, G.; Brattebø, H. Energy consumption, costs and environmental impacts for urban water cycle services: Case study of Oslo (Norway). Energy 2011, 36, 792-800. [CrossRef]

7. Baldocchi, D.; Falge, E.; Gu, L.; Olson, R.; Hollinger, D.; Running, S.; Anthoni, P.; Bernhofer, C.; Davis, K.; Evans, R. FLUXNET: A new tool to study the temporal and spatial variability of ecosystem-scale carbon dioxide, water vapor, and energy flux densities. Bull. Am. Meteorol. Soc. 2001, 82, 2415-2434. [CrossRef]

8. WHO Water Safety in Bbuildings; World Health Organization: London, UK, 2011; ISBN 924154810X.

9. Stenekes, N.; Colebatch, H.K.; Waite, T.D.; Ashbolt, N.J. Risk and governance in water recycling: Public acceptance revisited. Sci. Technol. Hum. Values 2006, 31, 107-134. [CrossRef]

10. Farley, M.; Trow, S. Losses in Water Distribution Networks; IWA publishing: London, UK, 2003; ISBN 1900222116.

11. Rosegrant, M.W.; Cai, X.; Cline, S.A. World Water and Food to 2025: Dealing with Scarcity; Intl Food Policy Res Inst: Washington, DC, USA, 2002; ISBN 0896296466.

12. Frauendorfer, R.; Liemberger, R. The Issues and Challenges of Reducing Non-Revenue Water; Asian Development Bank: Mandaluyong, Philippines, 2010; ISBN 9290921935.

13. UN-MDG. The Millennium Development Goals Report; UN-MDG: New York, NY, USA, 2015.

14. Xin, K.; Tao, T.; Lu, Y.; Xiong, X.; Li, F. Apparent losses analysis in district metered areas of water distribution systems. Water Resour. Manag. 2014, 28, 683-696. [CrossRef]

15. Lambert, A.O. International report: Water losses management and techniques. Water Sci. Technol. Water Supply 2002, 2, 1-20. [CrossRef]

16. Colombo, A.F.; Karney, B.W. Energy and costs of leaky pipes: Toward comprehensive picture. J. Water Resour. Plan. Manag. 2002, 128, 441-450. [CrossRef]

17. Covas, D.I.C.; Cláudia Jacob, A.; Ramos, H.M. Water losses' assessment in an urban water network. Water Pract. Technol. 2008, 3. [CrossRef]

18. Blokker, E.J.M.; Vreeburg, J.H.G.; Beverloo, H.; Klein Arfman, M.; Van Dijk, J.C. A bottom-up approach of stochastic demand allocation in water quality modelling. Drink. Water Eng. Sci. 2010, 3, 43-51. [CrossRef]

19. Taha, A.-W.; Sharma, S.; Kennedy, M. Methods of assessment of water losses in water supply systems: A review. Water Resour. Manag. 2016, 30, 4985-5001.

20. Mamade, A.; Loureiro, D.; Alegre, H.; Covas, D. Top-down and bottom-up approaches for water-energy balance in Portuguese supply systems. Water (Switzerland) 2018, 10, 577. [CrossRef] 
21. MacKenzie, D.R.; Bgagwan, J.N.; Lambert, A.O. Leakage Reduction Software Developed through The Water Research Commission. Available online: http://www.geocities.ws/kikory2004/10_mckenzie.pdf (accessed on 20 May 2019).

22. Puust, R.; Kapelan, Z.; Savic, D.A.; Koppel, T. A review of methods for leakage management in pipe networks. Urban Water J. 2010, 7, 25-45. [CrossRef]

23. Jensen, T.N.; Puig, V.; Romera, J.; Kallesøe, C.S.; Wisniewski, R.; Bendtsen, J.D. Leakage localization in water distribution using data-driven models and sensitivity analysis. Ifac-Papersonline 2018, 51, 736-741. [CrossRef]

24. Alonso, J.M.; Alvarruiz, F.; Guerrero, D.; Hernández, V.; Ruiz, P.A.; Vidal, A.M.; Martínez, F.; Vercher, J.; Ulanicki, B. Parallel computing in water network analysis and leakage minimization. J. Water Resour. Plan. Manag. 2000, 126, 251-260. [CrossRef]

25. Fontana, N.; Giugni, M.; Portolano, D. Losses reduction and energy production in water-distribution networks. J. Water Resour. Plan. Manag. 2011, 138, 237-244. [CrossRef]

26. Auriol, E.; Blanc, A. Capture and corruption in public utilities: The cases of water and electricity in Sub-Saharan Africa. Util. Policy 2009, 17, 203-216. [CrossRef]

27. Jacobsen, M.; Webster, M.; Vairavamoorthy, K. The Future of Water in African Cities: Why Waste Water? The World Bank: Washington, DC, USA, 2012; ISBN 0821397214.

28. Desalegn, W.B. Water Supply Coverage and Water Loss in Distribution Systems (The case of Addis Ababa); International Institute for Geo-Information Science and Earth Observation Enschede: Overijssel, The Netherlands, 2005.

29. Roy, M. Planning for sustainable urbanisation in fast growing cities: Mitigation and adaptation issues addressed in Dhaka, Bangladesh. Habitat Int. 2009, 33, 276-286. [CrossRef]

30. Emana, B. Cooperatives: A Path to Economic and Social Empowerment in Ethiopia; ILO: Geneva, Switzerland, 2009; ISBN 9221225623.

31. Leal, W. Climate Change Adaptation in Africa, 1st ed.; Filho, W.L., Belay, S., Kalangu, J., Menas, W., Munishi, P., Musiyiwa, K., Eds.; Springer International Publishing: New York, NY, USA, 2014; ISBN 978-3-319-84178-6.

32. Liemberger, R.; McKenzie, R. Aqualibre: A new innovative water balance software. In Proceedings of the IWA and AWWA Conference on Efficient Management of Urban Water Supply, Tenerife, Spain, 2-4 April 2003.

33. Charalambous, B.; Hamilton, S. Water balance - the next stage. Water Util. J. 2011, 1, 3-10.

34. Singto, C.; Fleskens, L.; Vos, J. Institutionalizing participation in water resource development: Bottom-up and top-down practices in southern Thailand. Water 2018, 10, 781. [CrossRef]

35. Evarts, J.C.; Swan, L.G. Domestic hot water consumption estimates for solar thermal system sizing. Energy Build. 2013, 58, 58-65. [CrossRef]

36. Thornton, J.; Sturm, R.; Kunkel, G. Water Loss Control; McGraw Hill Professional: New York, NY, USA, 2008; ISBN 0071640991.

37. Aymerich, I.; Rieger, L.; Sobhani, R.; Rosso, D.; Corominas, L. The difference between energy consumption and energy cost: Modelling energy tariff structures for water resource recovery facilities. Water Res. 2015, 81, 113-123. [CrossRef] [PubMed]

38. Hoque, S.F.; Wichelns, D. State-of-the-art review: Designing urban water tariffs to recover costs and promote wise use. Int. J. Water Resour. Dev. 2013, 29, 472-491. [CrossRef]

39. Marzano, R.; Rougé, C.; Garrone, P.; Grilli, L.; Harou, J.J.; Pulido-Velazquez, M. Determinants of the price response to residential water tariffs: Meta-analysis and beyond. Environ. Model. Softw. 2018, 101, 236-248. [CrossRef]

40. De Gans, H. Population Forecasting 1895-1945: The Transition to Modernity; Springer Science \& Business Media: Dordrecht, The Nertherlands, 1999; Volume 5, ISBN 0792355377.

41. Gleick, P.H. Basic Water Requirements for Human Activities: Meeting Basic Needs. Water Int. 1996, 21, 83-92. [CrossRef]

42. World Bank. The World Bank Data Catalog; World Bank: Washington, DC, USA, 2019.

43. Azevedo, B.B.; Saurin, T.A. Losses in Water Distribution Systems: A Complexity Theory Perspective. Water Resour. Manag. 2018, 32, 2919-2936. [CrossRef]

44. Gonza, J.; M1, R. Probabilistic leak detectability assessment via state estimation in water transport networks. Stoch. Environ. Res. Risk Assess. 2018, 32, 2111-2128. 
45. Romano, M.; Kapelan, Z.; Savić, D.A. Automated Detection of Pipe Bursts and Other Events in Water Distribution Systems. J. Water Resour. Plan. Manag. 2012, 140, 457-467. [CrossRef]

46. Salami, E.S.; Ehteshami, M. Simulation, evaluation and prediction modeling of river water quality properties (case study: Ireland Rivers). Int. J. Environ. Sci. Technol. 2015, 12, 3235-3242. [CrossRef]

47. Yaseen, Z.M.; El-shafie, A.; Jaafar, O.; Afan, H.A.; Sayl, K.N. Artificial intelligence based models for stream-flow forecasting: 2000-2015. J. Hydrol. 2015, 530, 829-844. [CrossRef]

48. Yaseen, Z.M.; Sulaiman, S.O.; Deo, R.C.; Chau, K.-W. An enhanced extreme learning machine model for river flow forecasting: State-of-the-art, practical applications in water resource engineering area and future research direction. J. Hydrol. 2019, 569, 387-408. [CrossRef]

49. Gupta, S.P.; Pandey, U.K. Data Analysis, Visualization, and Leak Size Modeling for Water Distribution Network. In Soft Computing and Signal Processing; Springer: Cham, Switzerland, 2019; pp. 77-83.

50. Li, X.; Khademi, F.; Liu, Y.; Akbari, M.; Wang, C.; Bond, P.L.; Keller, J.; Jiang, G. Evaluation of data-driven models for predicting the service life of concrete sewer pipes subjected to corrosion. J. Environ. Manag. 2019, 234, 431-439. [CrossRef] [PubMed]

51. Gao, J.; Qi, S.; Wu, W.; Han, A.; Chen, C.; Ruan, T. Leakage control of multi-source water distribution system by optimal pump schedule. Procedia Eng. 2014, 70, 698-706. [CrossRef]

52. Wu, Z.Y.; Sage, P.; Turtle, D. Pressure-Dependent Leak Detection Model and Its Application to a District Water System. J. Water Resour. Plan. Manag. 2010, 136, 116-128. [CrossRef]

53. Cooper, S.; Slack, R. Reporting practice, impression management and company performance: A longitudinal and comparative analysis of water leakage disclosure Reporting practice, impression management and company performance: A longitudinal and comparative analysis of water. Account. Bus. Res. 2015, 45, 4788. [CrossRef]

54. Diakité, D.; Semenov, A.; Thomas, A. A proposal for social pricing of water supply in Côte d'Ivoire. J. Dev. Econ. 2009, 88, 258-268. [CrossRef]

(C) 2019 by the authors. Licensee MDPI, Basel, Switzerland. This article is an open access article distributed under the terms and conditions of the Creative Commons Attribution (CC BY) license (http://creativecommons.org/licenses/by/4.0/). 